\title{
PERCEIVED BENEFITS OF SELECTED WETLANDS IN SOUTH-WEST NIGERIA
}

\author{
OLAREWAJU T.O., ${ }^{1, *}$ \\ SHITTU A.M. ${ }^{1}$ \\ OLUBANJO 0.0. ${ }^{3}$ \\ DIPEOLU A.O. ${ }^{1}$ \\ SODIYA C.I. ${ }^{2}$
}

\author{
${ }^{1}$ Department of Agricultural Economics \& Farm Management \\ Federal University of Agriculture \\ Abeokuta P.M.B. 2240, Nigeria \\ ${ }^{2}$ Department of Agricultural Extension \& Rural Sociology \\ Federal University of Agriculture \\ Abeokuta P.M.B. 2240, Nigeria \\ ${ }^{3}$ Department of Agricultural Economics \& Farm Management \\ Olabisi Onabanjo University \\ Yewa Campus, Ayetoro P.M.B 0012, Nigeria
}

Received: 17/10/2012

Accepted: 25/04/2013 *to whom all correspondence should be addressed: e-mail: titiquadri@yahoo.com

\section{ABSTRACT}

Poor appreciation of Wetlands has been linked to their massive destruction in Nigeria. This results in a considerable loss of benefits on income generation, food security and environment sustainability. This study assesses people's perception of benefits from selected Wetlands in South West, Nigeria. The study was based on primary data obtained in a cross-section survey of individuals that were either resident and/or pursuing livelihood activities in communities around selected Wetlands in Oyo, Ogun and Lagos states respectively. The study found that the majority of respondents appreciated the direct benefits of the Wetlands especially in terms of their role in the provision of food, herbs for medicinal uses and building materials while only a few appreciated its environmental services such as windbreak action nutrient recycling and microclimate stabilization. The level of appreciation of all Wetland benefits among the respondent was low. Results revealed that age, Wetland share of income, activity type and location of Wetland are factors that significantly influence people's perception of Wetlands benefits. It can therefore be concluded that people around Wetlands have a poor appreciation of their benefits especially those associated to environmental services they provide.

KEYWORDS: Likert scale, Perceived Benefit Index, Tobit regression and Policy.

\section{INTRODUCTION}

Wetlands - generally referring to marshes, swamps, floodplains, mudflats, estuarine and the littoral areas of large bodies of water - are used together with uplands in an integrated manner by the rural people to sustain livelihood. They are among the Earth's most productive ecosystems (Barbier et al., 1997). They have been described both as "the kidneys of the landscape", because of the functions they perform in the hydrological and chemical cycles, and as "biological supermarkets" because of the extensive food webs and rich biodiversity they support (Mitsch and Gosselink, 1993). Wetlands perform a wide variety of functions that include flood control, ground water recharge, shore line stabilization and storm protection, climate moderation and also serve as habitat for living things, recreation, tourism and cultural values (Federal Ministry of Environment, 2009; Bikangaga, 2007).

In Nigeria just like everywhere else in the World, floodplains and wetlands are rich sources of livelihood for millions of people yet; their destruction is taking place at an alarming rate, with as much as about 50\% of the World Wetlands already lost (O'Connell, 2003 ; RAMSAR, 2009). Nigeria's most important wetlands, the Hadejia-Nguru Wetlands in Jigawa and Yobe states respectively, have shrunk by as much as two-thirds in the past 30-40 years because of diversions from dams, irrigation developments and drought. Fisheries, farming and wildlife are all impacted by these hydrological changes (Idris, 2008) and by extension the livelihood sustenance of the local communities that 
depend on them. Also, uncontrolled oil exploration activities with the attendant oil spillage and pollution has caused a vast track of the agricultural land in the Niger-Delta Wetland (the largest in Nigeria, and the third largest RAMSAR designated site in the world) to be laid waste, thus becoming unproductive (Nigerian Environmental Study, 1991). As a result, surface water in the area is invariably contaminated and polluted, rendering the water undrinkable, and aquatic life destroyed, while the vast majority of the natives whose livelihoods depends largely on the Wetlands are equally impoverished. Most of these loses are unfortunately due to human activities, including large scale diversion of water for irrigation, burning and exploitation of peat land, extensive drainage of marshes, pollution of lakes and rivers (RAMSAR, 2009) Nevertheless, wetlands can be sustainably exploited if the dynamics of the local institutions that influence accumulationand consumption of livelihood assets are well understood and harnessed appropriately, (Mwakubo and Obare, 2009; Gren et al., 1994). The life support systems that are inherent within the wetland ecosystems can provide a wide range of valuable functions to society if they are used in a sustainable manner, for example, by incorporating the primary users in the management of the wetlands within the context of societal livelihoods and local institutions (Folke, 1991) as well as balancing the different use options so as to ensure sustainability of the resource. To achieve this, Springate-Baginski., et al. (2009) has opined that decentralization of management to the lowest appropriate level of all stakeholders will help achieve greater efficiency, effectiveness and equity. However, Martin and Sutherland (2003) in reviewing several projects in Malawi, has observed that an understanding of the immediate Wetland community dwellers perception of its benefits is very important. According to them it allows interventions to be targeted to specific groups for whom the problem is most acute. Furthermore, they opined that motivation for participation is strongly influenced by the relevance of the research focus and intervention strategy to stakeholders' priorities, roles and expectations of benefit. Therefore, an express knowledge of the values they associate with the Wetlands will be the fundamental step upon which correction in their values and the eventually sustainability programme hinges on. Also, more explicit understanding of this relationship has the potential to encourage the greater involvement of specific groups in monitoring and evaluation (Martin and Sutherland 2003). Studies of this nature are thus urgently required to critically assess people's perception of the benefits derivable from Wetlands for policy implications geared towards consideration of how to improve the complementarities of strategies for income generation, food security and environment sustainability.

Economically, wetlands are important for a nation as they improve water quality without expensive treatment facilities, curb flooding after large storm events which reduces potential damage to buildings, roads and infrastructure, and increase the enjoyment of our human habitat by providing places for important wildlife and plants to live (USEPA, 2006). The local communities in which wetlands are found have been known to depend on them for livelihoods as they are important source of employment, income, food and nutrition which helps in achieving a good health status (Friend, 2007). According to this report, people that live in wetland areas are wetland livelihoods - based, cultivating wetland crops and harvesting of a range of aquatic resources such as fish, crustaceans, amphibians and insects. Wetlands are therefore important to the locals in whose domain they occur and the mainstream economic activities of a nation.

Environmental income (income derived from the ecosystems) is a major constituent of the livelihoods of the rural poor (World Resources, 2005). According to this report, this reliance on the environment is now been explored as a veritable tool in economically empowering the rural poor especially in Africa, Asia, and Latin America. The importance of these resources as a sheet anchor can therefore not be overemphasized as any harm done to them will affect the livelihood of the people that depend on them. The broad objective of this study therefore was to assess the perception of wetlands benefits by the immediate community dwellers of selected wetlands in Southwest, Nigeria. The specific objectives were to describe and compare the socio-economic characteristics of various categories of Wetland service users in the study area, determine the benefits that the Wetland service users perceived they derive from the existence of the Wetlands in their area, and examine the influence of various socio-economic, attitudinal, location-specific, and other factors on the perceived value. 


\section{MATERIALS AND METHODOLOGY}

\subsection{Study Area}

This study was based on data obtained from a cross-section of 197 respondents from 17 communities around three Wetlands in Lagos, Ogun and Oyo state. These were Lagos Lagoon, Eriti in Ogun and Eleyele in Oyo states. Lagos was included based on the extensive wetland surface area in the state. Eriti Wetland was included because of its use for agricultural purposes and its consequent involvement in FADAMA programmes. Eleyele Wetland is a major source of portable water distributed for household use upon treatment in the area.

\subsection{Sampling Procedure}

Multi stage sampling technique was used in this study. Stage one involved the purposive selection of three Wetlands (Eleyele, Eriti and Lagos Wetlands). The second stage involved the random selection of eighteen communities close to the water bodies while the third stage involved systematic random selection of respondents from residential buildings and from farm/ nonfarm enterprises. Communities surveyed around Lagos Lagoon included Ebute Afuye/ Chief in Epe, Foolu, Ise, Odofin and Ibeju in Ibeju-Lekki, Itoga, and Ikoga Zebbe in Badagry. Those surveyed around Eleyele Wetland are Eleyele, ljokodo, Apete, Awotan and Olopomewa while the communities visited around the Eriti Wetland which is one of the tributaries of the Ogun- Oshun River are Eriti, Oluwo-Isale, Olorunda, Saare, and Mokoloki harbouring another Wetland which is also a part of the Ogun-Oshun River.

\subsection{Data Collection}

Primary data were used for this study. The data were collected through the use of personally administered questionnaire. Data consists of information on socio-economic as well as demographic characteristics of the respondents. Information was also obtained on the benefits that are derivable from these Wetlands as well the degree of importance the respondents attach to such benefits. Based on literature, the range of benefits presented to the respondents included:

- Access to fresh food produced around the Wetland at a cheaper price

- Provision of cool breeze

- Provision of sand and other building material

- Provision of recreation and tourist site

- Provision of clean air

- Provision of herbs and pharmaceuticals

- Helping to recharge ground water

- Serves as water storage facility thereby making water available all year round

- Help in controlling flood by accommodating run-off water

- Provision of wind breaks that serve as storm protection device

- Helping in nutrient recycle by retaining nutrient from eroded topsoil

- Micro-climate stabilization such as lowering of day and night temperature

Each respondent was required to specify whether the Wetland in his area offer provides benefits and the extent to which such benefits are important to him. Other data obtained included detailed data on direct utilization of Wetland services, the number of years the respondent has been living, or working in the Wetlands among others.

\subsection{Analytical Technique/ Measurement of Variables}

The analytical techniques employed for this study included both descriptive and quantitative techniques. The details of analytical techniques, for each of the specific objectives, are as follows: 


\section{Description and Comparison of Socio-economic Characteristics}

Simple frequency and cross-tab tables were used to facilitate description of socio-economic characteristics of the sampled respondents, and comparison of socio-economic characteristics of different categories of Wetland service users.

\section{Measurement of Perceived Benefits}

A respondent perceives a wetland benefit when he agrees that the benefit is either "important" or "very important". But he does not perceive a benefit if such is rated as "not recognized" or "not important" on the likert scale. In calculating the PBI, a score of one ( $S=1)$ was assigned if a respondent believes the Wetland in his area renders a particular benefit to the immediate society while failure to perceive such benefit attracted a score of zero $\left(S_{j}=0\right)$. The perception score was then weighted on a Likert scale to determine the level of importance a respondent personally attach to such benefit. From this, the perception index for each respondent was computed based on all the benefits presented to them. The value of $\mathrm{PBI}$ falls between zero and one. PBI value that is less than 0.45 is considered low, between 0.45 and 0.64 is termed moderate while $\mathrm{PBI}$ values greater than 0.64 is high perception. The higher the $\mathrm{PBI}$, the greater the value the respondent attached to the Wetland.

\section{Determinant of Perceived Benefits}

The influences of various socio-economic factors on the respondents' perceived benefits (measured by the Perceived Benefit Index - PBI) were examined by specifying and estimating the following Tobit regression model. The choice of Tobit regression model is hinged on the fact that it allows censoring as well as corner solution for optimal choice. Also, the model accommodates heteroskedasticity in $\operatorname{var}(\mathrm{y} \mid \mathrm{x})$. Although this weakness may be overcome by using the Weighted Non Linear Least Square in place of the Non Linear Least Square which is equally favoured but deficient in this last regard. It is however noteworthy that the effects of $x_{j}$ on $y$ cannot be measured using this approach (Woolridge, 2002). Censored Tobit model is well suited in a situation where the dependent variable jumps discreetly at zero (Koutsoyianis, 1982). The standard Censored Tobit model is

$y^{*}=X_{i} \beta+u_{i} \quad u_{i} \mid X_{i} \sim$ Normal $\left(0, \sigma^{2}\right)$

$\mathrm{y}_{\mathrm{i}}=\max \left(0, \mathrm{y}_{\mathrm{i}}^{*}\right)$

This is explicitly applied in this study as

$$
\begin{aligned}
& P B I^{*}=X_{i} \beta+u_{i} \quad u_{i} \mid X_{i} \sim \text { Normal }\left(0, \sigma^{2}\right) \\
& P B I_{i}=\beta_{o}+\beta_{j} X_{i j}+u_{i}
\end{aligned}
$$

\section{Where;}

$\mathrm{PBI}_{i} \quad$ is the Perceived Benefit Index of the $\mathrm{i}^{\text {th }}$ respondent

$\mathrm{X}_{1} \quad=$ Age (years)

$\mathrm{X}_{2} \quad=$ Age Square (years)

$\mathrm{X}_{3}=\operatorname{Sex}(1$ if Female 0 if Male)

$\mathrm{X}_{4} \quad=$ Education (years of schooling)

$\mathrm{X}_{5} \quad=$ No of years living, working or visiting the area (years)

$X_{6} \quad=$ Respondent's income from all sources (naira/year)

$\mathrm{X}_{7}=$ Share of total income derived from Wetland related activities (naira/year)

$\mathrm{X}_{8 \mathrm{j}} \quad=\mathrm{A}$ set of dummy variables for various categories of respondent

( $\mathrm{j}=0,1, ., \mathrm{k}$ for residents, farmer, fisher-folks, resource collection, other occupation). It takes a value of 1 if respondent belong to the $\mathrm{j}^{\text {th }}$ category, and 0 if otherwise.) The dummy variable for residents $(\mathrm{j}=0)$ was dropped in the estimation. 
$\mathrm{X}_{9}=$ Wetland location (A set of dummy variables for various Wetland location $(\mathrm{j}=0,1,2$ for urban, sub urban and rural location). It takes a value of 1 if respondent belong to the $\mathrm{j}^{\text {th }}$ category, and 0 if otherwise.) The dummy variable for rural location $(j=0)$ was dropped in the process of estimation.

\section{RESULTS, DISCUSSION AND RECOMMENDATIONS}

\subsection{Characteristics of Wetland Users}

Three main categories of users of Wetland services were identified among the survey respondents as shown in Figure 1. An exploration of Figure 1 shows that majority $(94.7 \%, 74.2 \%$, and $70.4 \%)$ of the respondents in Eleyele, Eriti, and Lagos Lagoon both live and pursue livelihood (indirect and direct users respectively) around all the Wetlands respectively. The same trend is also observed in the pooled data $(74.6 \%)$ irrespective of the Wetland location. This shows that irrespective of their location, Wetlands are actively explored by their surrounding community in generating income. Also, the figure revealed $14.2 \%$ of the respondents come from outside the immediate environment of the Wetland (direct users) to pursue livelihood activities. This by implication further shows that it is not only the Wetland community dwellers that depend on the Wetland for livelihood sustenance.

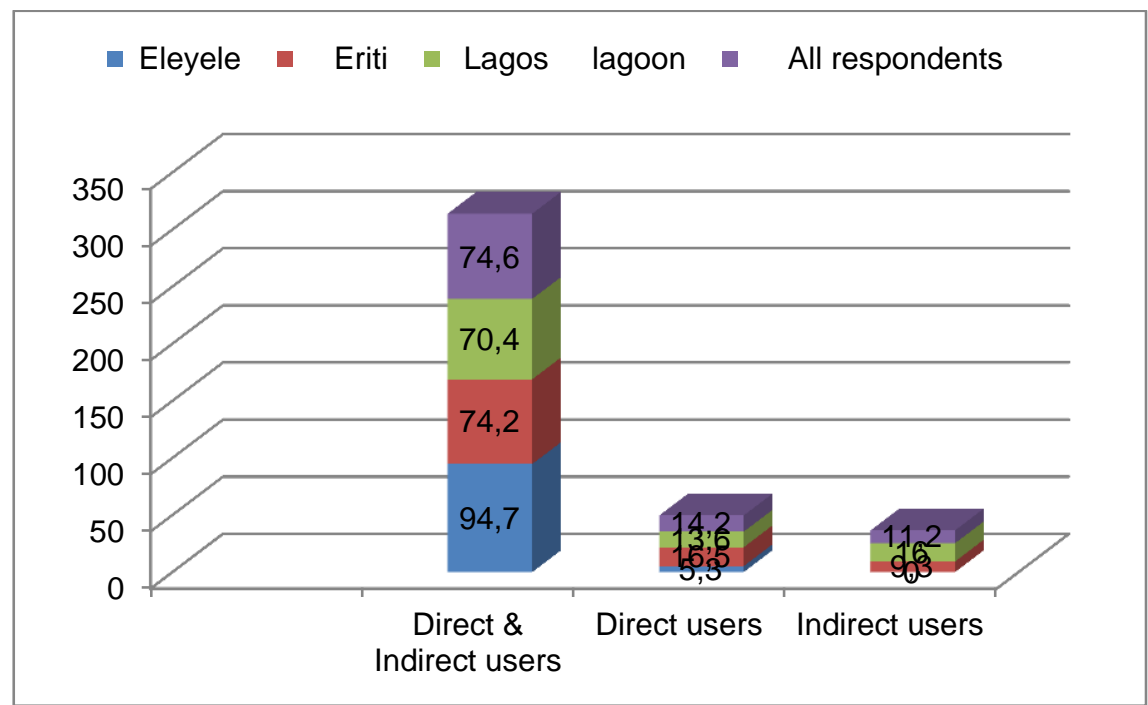

Figure 1. Distribution of Respondents by Location and type of Wetland Use

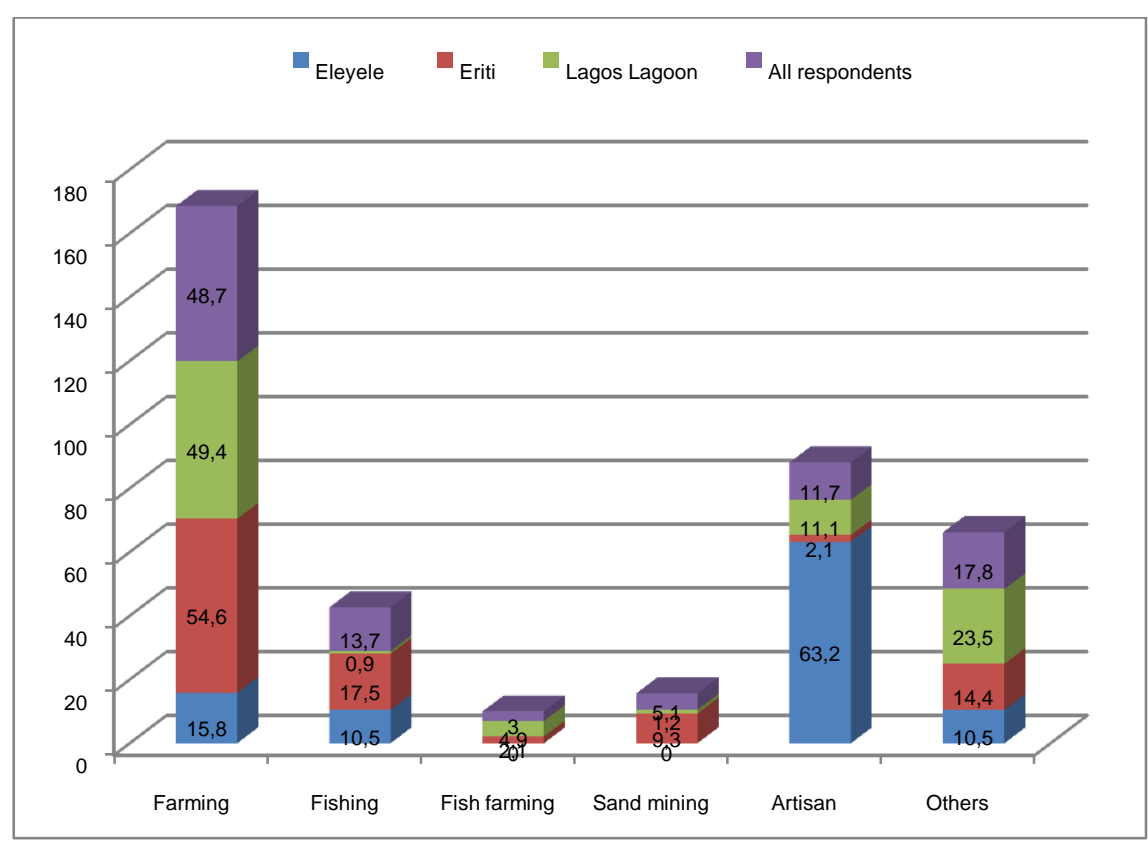

Figure 2. Distribution of Respondents by Main Occupation 
The Figure 2 however suggests that about half (48.7\%) of the people around Wetlands are involved in crop farming. Farming is thus the major activity that these Wetlands are being used for although large proportions $(63.2 \%)$ of the people found around the Eleyele Wetland are artisans. This may be due to the fact that part of this water body is found in a commercial area (Eleyele Motor Park) while around the Lagos Wetlands other non-wetland livelihood activities such as food vending, trading, transport services, civil service etc constitute about $23.5 \%$ of the occupation.

\subsection{Socio Economic Characteristics of Wetland Users}

Socio economic characteristics of the respondents as shown on Table 1 reveals that majority of the survey respondents and by extension people resident and or pursuing livelihood activities around the selected Wetlands are economically active, aged between $31-50$ years $(54.5 \%)$ and mostly $(90.4 \%)$ married. They are predominantly educated either to the primary $(35.5 \%)$ or secondary $(39.1 \%)$ school level, with as much as $12.7 \%$ of them having no formal education. In terms of gender, although both sexes are involved in Wetland related activities, the male folk however constitute the majority (73.6\%). By religion, the Christians constitute a slight majority (59.4\%) as against the Muslims (40.6\%). Also, the Table reveals that majority (64.4\%) of the respondents have spent at least 10years either residing and or pursuing livelihood activities around the Wetlands.

Table 1. Distribution of Respondents by Personal Characteristics

\begin{tabular}{|c|c|c|c|c|}
\hline \multirow[b]{2}{*}{ Description } & \multicolumn{4}{|c|}{ Wetland Service User Category } \\
\hline & Direct users & Indirect users & $\begin{array}{c}\text { Direct \& } \\
\text { Indirect users }\end{array}$ & All respondents \\
\hline $\begin{array}{l}\text { Number of } \\
\text { respondents }\end{array}$ & $28(14.2 \%)$ & $22(11.2 \%)$ & $147(74.6 \%)$ & $197(100.0 \%)$ \\
\hline \multicolumn{5}{|l|}{ Age Group } \\
\hline Below 30 & $6(21.4 \%)$ & $2(9.1 \%)$ & $27(18.5 \%)$ & $35(17.9 \%)$ \\
\hline $31-40$ & $8(28.6 \%)$ & 7 (31.8\%) & $48(32.9 \%)$ & $63(32.1 \%)$ \\
\hline $41-50$ & $7(25.0 \%)$ & $8(36.4 \%)$ & $29(19.9 \%)$ & $44(22.4 \%)$ \\
\hline $51-60$ & $4(14.3 \%)$ & $5(22.7 \%)$ & $25(17.1 \%)$ & $34(17.3 \%)$ \\
\hline Above 60 & $3(10.7 \%)$ & $0(0.0 \%)$ & $17(11.6 \%)$ & $20(10.2 \%)$ \\
\hline \multicolumn{5}{|l|}{ Sex } \\
\hline Female & $4(14.3 \%)$ & $10(45.5 \%)$ & $38(25.9 \%)$ & $52(26.4 \%)$ \\
\hline Male & $24(85.7 \%)$ & $12(54.5 \%)$ & $109(74.1 \%)$ & $145(73.6 \%)$ \\
\hline \multicolumn{5}{|l|}{ Marital Status } \\
\hline Married & $25(89.3 \%)$ & $17(77.3 \%)$ & $136(92.5 \%)$ & $178(90.4 \%)$ \\
\hline Single & $2(7.1 \%)$ & $3(13.6 \%)$ & $7(4.8 \%)$ & $12(6.1 \%)$ \\
\hline Widow(er) & $1(3.6 \%)$ & $2(9.1 \%)$ & $4(2.7 \%)$ & $7(3.6 \%)$ \\
\hline \multicolumn{5}{|l|}{ Educational Level } \\
\hline No Formal education & $2(7.1 \%)$ & $4(18.2 \%)$ & $19(12.9 \%)$ & $25(12.7 \%)$ \\
\hline Primary & $9(32.1 \%)$ & $5(22.7 \%)$ & $56(38.1 \%)$ & $70(35.5 \%)$ \\
\hline Secondary & $13(46.4 \%)$ & $10(45.5 \%)$ & $54(36.7 \%)$ & $77(39.1 \%)$ \\
\hline Tertiary & $4(14.3 \%)$ & $3(13.6 \%)$ & $18(12.2 \%)$ & $25(12.7 \%)$ \\
\hline \multicolumn{5}{|l|}{ Religion } \\
\hline Christian & $19(67.9 \%)$ & $14(63.6 \%)$ & $84(57.1 \%)$ & $117(59.4 \%)$ \\
\hline Muslim & $9(32.1 \%)$ & $8(36.4 \%)$ & $63(42.9 \%)$ & $80(40.6 \%)$ \\
\hline \multicolumn{5}{|l|}{$\begin{array}{c}\text { Years spent around } \\
\text { the Wetland }\end{array}$} \\
\hline Less than 5 & $6(21.4 \%)$ & $2(9.1 \%)$ & $25(17.0 \%)$ & $33(16.8 \%)$ \\
\hline $5-10$ & $5(17.9 \%)$ & $8(36.4 \%)$ & $24(16.3 \%)$ & $37(18.8 \%)$ \\
\hline $11-15$ & $9(32.1 \%)$ & $5(22.7 \%)$ & $31(21.1 \%)$ & $45(22.9 \%)$ \\
\hline $16-20$ & $3(10.7 \%)$ & $3(13.6 \%)$ & $18(12.3 \%)$ & $24(12.1 \%)$ \\
\hline Greater than 20 & $5(17.9 \%)$ & $4(18.2 \%)$ & $49(33.3 \%)$ & $58(29.4 \%)$ \\
\hline TOTAL & $28(100.0 \%)$ & $22(100.0 \%)$ & $147(100.0 \%)$ & $197(100.0 \%)$ \\
\hline
\end{tabular}

Source: Data from Field Survey 2010 


\subsection{Perception of Wetland Benefits}

Results on Figure 3 shows the benefits clearly perceived by the respondents as; provision of food $(67.5 \%)$, provision of herbs $(54.3 \%)$ and provision of sand and other building materials $(59.4 \%)$. Those that were not perceived are windbreaks action $(71.1 \%)$, nutrient recycling $(68.1 \%)$ and microclimate stabilization (58.8\%). Incidentally, food and sand are some of the Wetland resources that are being actively explored by the people for income generation. Furthermore, the three benefits recognised by the majority of the people are direct benefits of the Wetlands while those poorly recognised are indirect benefits of the Wetlands which are its contribution in balancing the ecosystem. Although recreation and tourism is another income generating potential of the Wetland, this is also not perceived by more than half $(67.5 \%)$ of the Wetland users as such avenue of income generation is presently not being actively explored. Thus their perception of the Wetland benefits is limited to the present income generating potentials of the Wetlands.

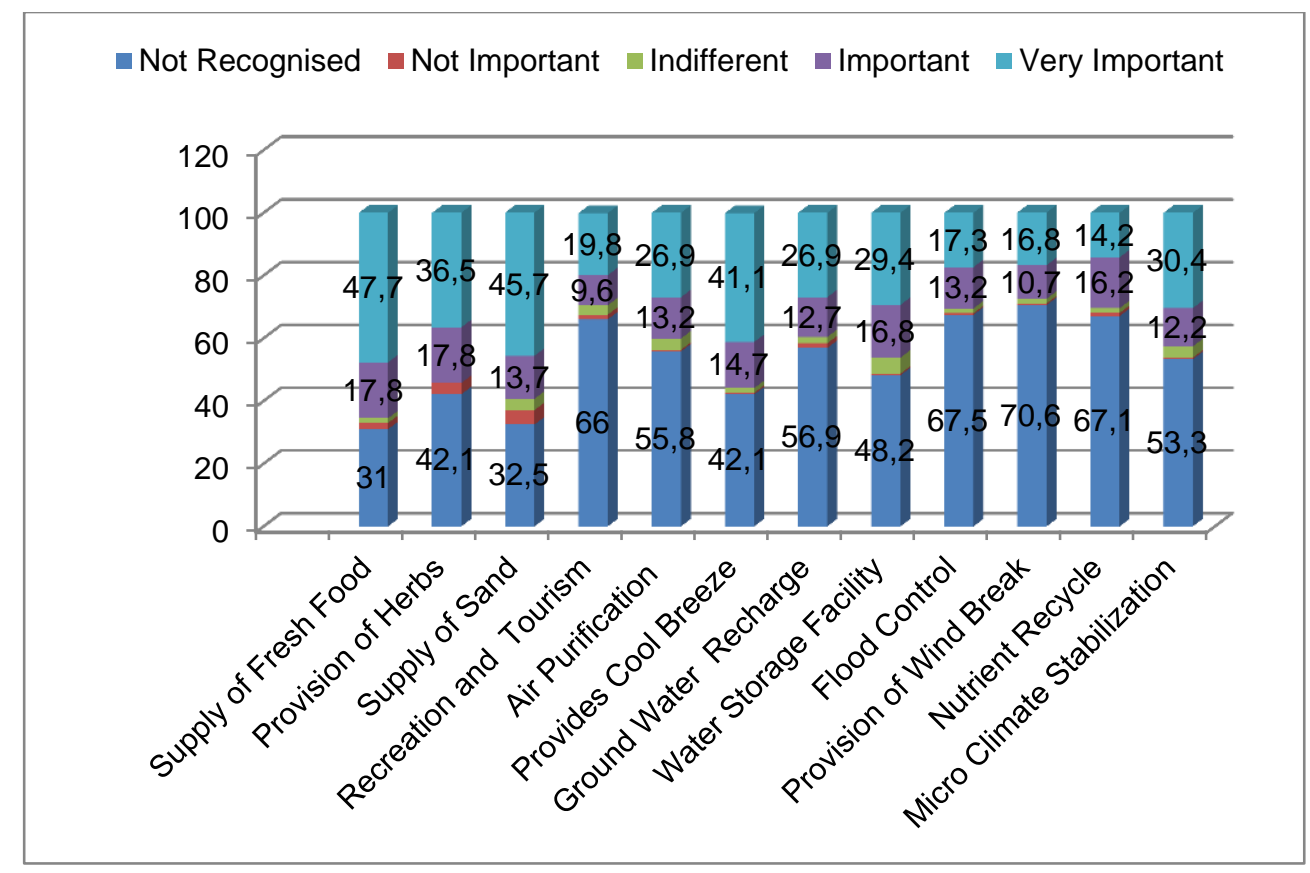

Figure 3. Respondent Perception of Wetland Benefits

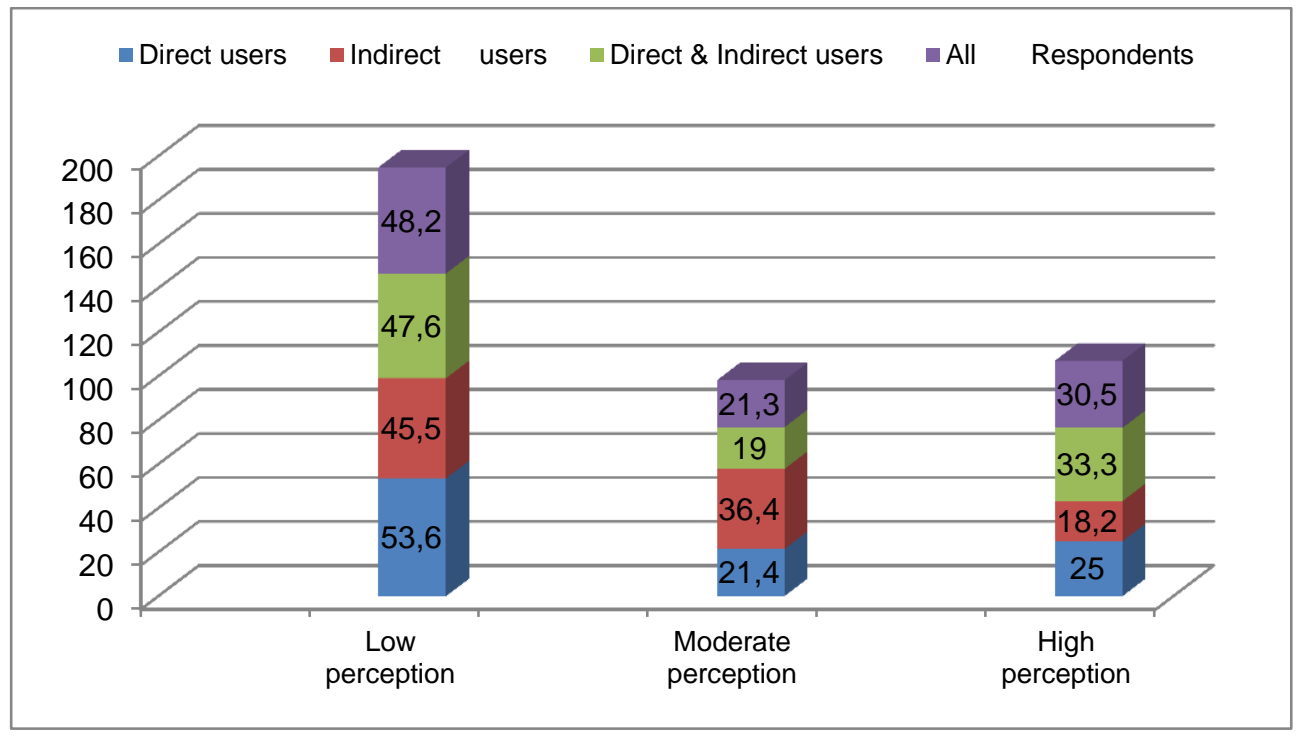

Figure 4. Distribution of Respondents by Overall Perception Score

(Source: Data from Field Survey 2010) 


\subsection{Perceived Benefit Index}

The overall strength of the respondent's recognition of all the benefits combined is shown by Perceived Benefit Index (PBI). Figure 4 presents this result across the different categories of Wetland service users. The table shows that almost half (48.2\%) of the respondents have low / poor perception of the Wetland benefits and this is unaffected even by the category of the Wetland service users. It can thus be inferred that a respondent who live and or pursue livelihood around these Wetlands have low perception or appreciation of all the Wetland benefits presented to them in this study.

\subsection{The Determinants of Perceived Benefit Index.}

In Table 2, Age, age square, total income and the share of the income that is derived from the Wetland were discovered to be the socio economic factors that influence people's perception of the Wetland benefits.

Table 2. Estimated Tobit Model of Perceived Benefit Index

\begin{tabular}{lccc}
\hline \multirow{2}{*}{ Explanatory Variables } & \multicolumn{2}{c}{ Regression Parameters } & \multirow{2}{*}{ Marginal Effect } \\
\cline { 2 - 3 } & Coefficient & t-ratio & \\
\hline Constant & -0.5223 & -1.3462 & $0.7227 \mathrm{E}-02$ \\
\hline Age & $0.3336 \mathrm{E}-01^{* *}$ & 1.9910 & $-0.8574 \mathrm{E}-04$ \\
\hline Age Square & $-0.3958 \mathrm{E}-03^{* *}$ & -2.1867 & $0.1517 \mathrm{E}-01$ \\
\hline Female dummy & $0.7004 \mathrm{E}-01$ & 0.8107 & $0.3002 \mathrm{E}-03$ \\
\hline Education in years & $0.1386 \mathrm{E}-02$ & 0.1694 & $0.5864 \mathrm{E}-03$ \\
\hline Years spent around Wetland & $0.2707 \mathrm{E}-02$ & 1.0049 & $-0.3000 \mathrm{E}-07$ \\
\hline Total Income & $-0.1406 \mathrm{E}-06^{* * *}$ & -2.6005 & $0.4326 \mathrm{E}-01$ \\
\hline Wetland share of income & $0.1997^{* *}$ & 2.4157 & $-0.7799 \mathrm{E}-02$ \\
\hline Farming & $-0.3601 \mathrm{E}-01$ & -0.4645 & $0.3801 \mathrm{E}-01$ \\
\hline Fishing & $0.1755^{* *}$ & 2.1937 & $-0.3502 \mathrm{E}-01$ \\
\hline Resource Collection & -0.1617 & -1.5844 & $-0.3943 \mathrm{E}-01$ \\
\hline Other livelihood options & -0.1820 & -1.6291 & -0.1309 \\
\hline Sub urban dummy & $-0.6041^{* *}$ & -5.8979 & $-0.1705 \mathrm{E}-01$ \\
\hline Urban dummy & $-0.7870 \mathrm{E}-01$ & -0.9395 & \\
\hline Log-likelihood function & -260.4342 & & \\
\hline Predicted F (I) & 0.2166 & & \\
\hline Squared correlation & 0.1595 & & \\
\hline
\end{tabular}

NOTE: ${ }^{* * * * *}, "$ implies that associated parameter is significant at $p<0.01, p<0.05$ and $p<0.10$ levels respectively

Also, the higher their total income the lesser they perceive the Wetland as being beneficial while in contrast, the higher the portion of this income that comes from the Wetland the more beneficial they regard them. These therefore go on to show that it's only the direct use value of the Wetlands that are appreciated as those who don't depend on the Wetland for income generation are likely to view them as less beneficial. Among the activity types, it was only the coefficient of fishing that was significant and also positive. A fisherman thus perceives the Wetland benefit better than a resident which is the reference category. This may be because of all the activity types, fishing is the one that depend entirely on the Wetland as they "only harvest without sowing" any substantial input into the Wetland. The suburban dummy coefficient was also significant but negative. This reveals that a respondent in a sub urban area perceives the Wetland in his/her area as less beneficial when compared with the rural Wetland people's perception of their own. 


\section{CONCLUSIONS AND POLICY RECOMMENDATION}

The major conclusions from the foregoing in this study are summarized as follows;

Firstly, Wetlands regardless of their location are being explored for various income generating activities. This if combined with conservational plans for these Wetlands will help enhance their functioning for this purpose and that of ecosystem balancing.

Secondly it was discovered that the use i.e. direct use values of the Wetlands, are better perceived by the people and their perception increases with the share of their income that comes from the Wetland as against a reduction with a higher total income. This implies that they rank and appreciate the use values better than the non use values.

Thirdly, age, being female, years of education, and wetland share of income all have positive influence on perception.

The study therefore concludes that Wetland and especially their roles in ecosystem functioning are lowly perceived by the people Based on these findings, the study recommends that; the economically active youth who both live and depend on wetlands for income generation should be educated on the goods and services associated with wetlands. Awareness should be created about all the benefits and impacts people's activities have on Wetlands in order to stimulate future sustainable use.

\section{REFERENCES}

Barbier E.B., Acreman M. and Knowler D. (1997), Economic Valuation of Wetlands: A guide for policy makers and planners, Ramsar Convention Bureau, Gland, Switzerland, Pages 71-72.

Bikangaga S., Picchi M.A., Focardi S. and Rossi C. (2007), Perceived Benefits of Littoral Wetlands In Uganda: A Focus On The Nabugabo Wetlands, Ecological Management, 15, 529-535.

Federal Ministry of Environment (2009), Press Release on World Wetland Day Celebration, $2^{\text {nd }}$ Feb 2009.

Folke C (1991), Socio-economic dependence on the life-supporting environment, In: Linking the natural environment and the economy: essays from the eco-ecogroup, Folke C, Kabeger T (eds), Kluwer, Dordrecht, pp 77-94.

Friend R. (2007), Securing sustainable livelihoods through wise use of wetland resources, Reflections on the experience of the Mekong Wetlands Biodiversity Conservation and Sustainable Use Programme (MWBP). Published by: Mekong Wetlands Biodiversity Conservation and Sustainable Use (MWBP). Vientianne, Lao PDR.

Gren I.M, Folke C., Turner K. and Bateman I. (1994), Primary and secondary values of wetland ecosystems, Environmental Resource Economics, 4, 55-74.

Idris M. (2008), Damming Nigeria's wetlands People: Communities Work Together to Restore Lives and Livelihoods, World Rivers Review: Legacy Issue.

Koutsoyianis A. (1982), Theory of Econometrics, Palgrave Publisher Ltd (Formerly Macmillan Publisners), $2^{\text {nd }}$ Edition

Martin A. and Sutherland A. (2003), Soil and Water Research in Malawi, Participatory Management of Kapuwai's Wetlands in Uganda, Forging New Institutional Arrangements For Common Property Resource Management - A Case Study From Southern Zimbabwe, In: Managing Natural Resources for Sustainable Livelihoods: Uniting Science and Participation, Pound B., Snapp S., McDougall C. and Braun A (eds). Earthscan Publications Ltd and the International Development Research Centre (IDRC) ISBN: 1-84407-206-3 Pages 48-60.

Mitsch W.J. and Gosselink J.G. (1993), Wetlands'. John Wiley \& Sons (formerly Van Nostrand Reinhold), New York, ISBN 044200805 8. Pages 6-8.

Mwakubo M.A and Obare G.A (2009), Vulnerability, Livelihood Assets and Institutional Dynamics in the Management of Wetlands in Lake Victoria Watershed Basin, Wetland Ecology and Management, 17, 613-626.

Nigerian Environmental Study/ Action Team (1991) Nigeria's Threatened Environment: A National Profile'.

O'Connell M.J (2003), Detecting, Measuring and Reversing Changes to Wetlands, Wetlands Ecology and Management, 11, 397-401, 2003. 
Ramsar (2009), Wetlands and the Climate Change Meeting UNFCCC COP15 Briefing Note From The Ramsar Scientific \& Technical Review Panel (STRP) And Secretariat To Contracting Parties. Copenhagen.

Springate-Baginski O., Allen D. and Darwall W. (2009), An Integrated Wetland Assessment Toolkit : A Guide to Good Practice International Union For Conservation of Nature and Natural Resource ISBN-13: 9782831711195.

United State Environmental Protection Agency (2006): Economic Benefits of Wetlands, EPA843-F-06-004 Office of Water.

Woolrigde J. M (2002), Economic Analysis of Cross Section and Panel Data, The MIT Press Cambridge Massachuttes London, England.

World Resources Institute, World Resources, 2005: The Wealth of the Poor: Managing Ecosystems to Fight Poverty, The University of Michigan, ISBN 1569735824, 9781569735824. 